\title{
Balding hair follicle dermal papilla cells contain higher levels of androgen receptors than those from non-balding scalp
}

\author{
N A Hibberts, A E Howell and V A Randall \\ Department of Biomedical Sciences, University of Bradford, Bradford BD7 1DP, UK \\ (Requests for offprints should be addressed to V A Randall, Department of Biomedical Sciences, University of Bradford, Bradford, BD7 1DP, UK)
}

\begin{abstract}
Androgens can gradually transform large scalp hair follicles to smaller vellus ones, causing balding. The mechanisms involved are unclear, although androgens are believed to act on the epithelial hair follicle via the mesenchymederived dermal papilla. This study investigates whether the levels and type of androgen receptors in primary lines of cultured dermal papilla cells derived from balding scalp hair follicles differ from those of follicles from non-balding scalp.

Androgen receptor content was measured by saturation analysis using the non-metabolisable androgen, $\left[{ }^{3} \mathrm{H}\right]$ mibolerone $(0 \cdot 05-10 \mathrm{nM})$ in a $9-10$ point assay. Pubic dermal fibroblasts and Shionogi cells were examined as positive controls. Repetitive assays of Shionogi cells showed good precision in the levels of androgen receptor content (coefficient of variation $=3 \cdot 7 \%$ ). Specific, high affinity, low capacity androgen receptors were detected in dermal
\end{abstract}

papilla cells from both balding and non-balding follicles. Balding cells contained significantly $(P<0 \cdot 01)$ greater levels of androgen receptors $\left(\mathrm{B}_{\max }=0.06 \pm 0.01 \mathrm{fmol} / 10^{4}\right.$ cells (mean \pm s.E.M.)) than those from non-balding scalp $(0 \cdot 04 \pm 0 \cdot 001)$. Competition studies with a range of steroids showed no differences in receptor binding specificity in the two cell types.

The higher levels of androgen receptors in cells from balding scalp hair follicles with similar properties to those from non-balding scalp concur with the expectations from their in vivo responses to androgens. This supports the hypothesis that androgens act via the dermal papilla and suggests that cultured dermal papilla cells may offer a model system for studying androgen action in androgenetic alopecia.

Journal of Endocrinology (1998) 156, 59-65

\section{Introduction}

Male pattern baldness is the most common form of baldness observed in human beings; its many synonyms include androgenetic alopecia, common baldness and androgenic alopecia. It follows a characteristic pattern, with the hair initially receding bilaterally backwards from the frontal-temporal region; in severe cases, regression of the hair line continues, denuding the crown region of the scalp (Hamilton 1951). Interestingly, a horse-shoe shaped area of occipital scalp region is consistently spared in male pattern baldness, suggesting a different end-organ response in these hair follicles to the factor(s) causing baldness in other scalp hair follicles. Although human hair growth is affected by thyroid (Jackson et al. 1972) and glucocorticoid (Stenn et al. 1993) hormones, pregnancy (Lynfield 1960), and season (Randall \& Ebling 1991), androgens are the most obvious regulators of normal human hair growth (reviewed by Randall 1994) and are a prerequisite for male pattern baldness (Hamilton 1942). Paradoxically, androgens stimulate growth in many body areas such as beard and axilla. The importance of androgens in hair growth is clearly demonstrated by patients with testicular feminisa- tion who have no functional androgen receptor. These individuals do not develop normal beard, pubic or axilla hairs and there have been no reports of male pattern baldness (Griffin \& Wilson 1989).

The hair follicle is a three-dimensional tube, composed mainly of epithelial cells, that protrudes down through the epidermis and dermis of the skin, enveloping at its base the mesenchyme-derived dermal papilla. The hair follicle undergoes successive cyclic periods of growth, involving an active growing phase (anagen) during which the previous hair is shed, a short transitionary regressive phase (catagen) and a dormant resting phase (telogen) (Kligman 1959), which allow the follicle to produce different types of hair in response to hormonal changes. The molecular mechanisms involved in the control of this cycle are not understood, but it is believed that the dermal papilla plays an important role in the induction and maintenance of epithelial cell growth (Oliver 1970, Reynolds \& Jahoda 1991). The dermal papilla has also been shown to be critical in the development of the hair follicle (Hardy 1992) and exerts a controlling influence on other characteristics such as hair diameter (Van Scott \& Ekel 1958, Ibrahaim \& Wright 1982). 
Androgens are believed to act on the hair follicle via the mesenchyme-derived dermal papilla, altering the production of soluble mitogenic factors and/or extracellular matrix factors which then influence the surrounding follicular epithelial cells (Randall et al. 1991, Randall 1994). The culture of dermal papilla cells from the larger non-balding scalp and body hair follicles is well established (Messenger 1984) and they appear to offer a useful model for studying the action of androgens. Dermal papilla cells in vitro have been shown to retain their in vivo inductive properties (Reynolds \& Jahoda 1991) and to display properties which are dependent on their in vivo sensitivities to androgens (Itami et al. 1991, Randall et al. 1992, Thornton et al. 1993, Itami et al. 1995, Hamada et al. 1996). The correlation between the patterns of testosterone metabolism by dermal papilla cells derived from beard, scalp, pubic and axillary hair follicles (Itami et al. 1991, Thornton et al. 1993, Hamada et al. 1996) and hair growth in $5 \alpha$-reductase deficiency syndromes (ImperatoMcGuinley et al. 1991) strongly supports the hypothesis that androgens act via the dermal papilla.

Since the difficult culture of dermal papilla cells from smaller balding scalp hair follicles has recently been established (Randall et al. 1996), this study has been carried out to compare the levels of androgen receptors and their binding specificity in dermal papilla cells derived from balding and non-balding scalp hair follicles in an attempt better to understand the roles of androgens in androgenetic alopecia. Pubic dermal fibroblasts and Shionogi mouse mammary carcinoma cells were also assayed to serve as positive controls and to assess the precision of the assay, as both cell types are established model systems for androgen action (Evans et al. 1984, Jung-Testas \& Baulieu 1987).

\section{Materials and Methods}

\section{Cell culture}

Primary cultures of dermal papilla cells were derived from frontal (balding) and occipital (non-balding) human scalp hair follicles as described by Randall et al. (1996). Lines were derived from 10 men and 1 woman (an occipital sample) with mean ages of 34 (range $=25-47$ ) for balding scalp and 34 years (range $=25-47$ ) for occipital scalp. Briefly, full depth punch biopsies were obtained from balding (frontal) and non-balding (occipital) regions of the scalp. The skin samples were waste material from healthy individuals undergoing cosmetic surgery. The dermal papilla was microdissected from each individual hair follicle using a Wild dissecting microscope (Leitz, UK). This procedure is manually intensive and, particularly with the smaller balding scalp dermal papillae, requires considerable patience and dexterity. Dermal papilla were isolated from the small intermediate follicles in the balding scalp and not from the tiny vellus follicles because the former are actually undergoing the changes due to androgens and also for practical reasons because of the extreme technical difficulties of obtaining dermal papillae from vellus follicles.

Four or five isolated dermal papillae were placed in sterile $35 \mathrm{~mm}$ tissue culture dishes in medium E199 supplemented with L-glutamine $(2 \mathrm{mM}$ ) (Sigma Chemical Company, Poole, Dorset, UK), penicillin $(100 \mathrm{U} / \mathrm{ml}) /$ streptomycin $(100 \mu \mathrm{g} / \mathrm{ml})$ solution (Gibco, Paisley, Strathclyde, UK) and Fungizone $(2.5 \mu \mathrm{g} / \mathrm{ml})$ (Sera-Lab, Crawley Down, W. Sussex, UK) (termed dermal papilla cell medium) and 20\% (v/v) pooled human female serum and placed in a humidified incubator containing 5\% $\mathrm{CO}_{2}$. Cells were checked at regular intervals using phase contrast microscopy and, when sufficient cells were present, they were transferred to sterile $25 \mathrm{~cm}^{2}$ tissue culture flasks. Cells were cultured in dermal papilla cell medium supplemented with $10 \%$ (v/v) pooled human female serum until confluent when they were subcultured successively into further flasks with a split ratio of 1:3. All tissue culture plastics were supplied by Corning Laboratories, Nottingham, UK. Balding and non-balding scalp dermal papilla cells at passage number 5 were used for all investigations. It took $2-3$ months for each cell line to produce sufficient cells for an assay due to the small size of the skin samples and the slow growth of the dermal papilla cells, particularly from the balding scalp.

\section{Shionogi cells}

Cells from the continuous cell line of mouse mammary carcinoma Shionogi S115 were cultured in Dulbecco's Modified Essential Medium (DMEM) supplemented with the dermal papilla cell media plus $2 \%(\mathrm{v} / \mathrm{v})$ fetal bovine serum.

\section{Human serum}

Human serum used in all procedures was obtained from the Blood Transfusion Service, Sheffield from female blood donors aged 18-50 years. Serum was filtered $(0 \cdot 2 \mu \mathrm{m})$ and stored at $-20{ }^{\circ} \mathrm{C}$ until required.

\section{Preparation of charcoal-stripped serum}

To remove any androgens from the female human serum, Norit A charcoal $(0 \cdot 25 \% \mathrm{w} / \mathrm{v})$ and T-70 dextran $(0 \cdot 0025 \%$ $\mathrm{w} / \mathrm{v})$ were incubated in $0.25 \mathrm{M}$ sucrose $/ 1.5 \mathrm{mM} \mathrm{MgCl}_{2} /$ 10 mM HEPES, pH $7 \cdot 6$ at $4{ }^{\circ} \mathrm{C}$ overnight. All chemicals were supplied by Sigma Chemical Company. A volume of the dextran-coated charcoal was centrifuged at $500 \mathrm{~g}$ for $10 \mathrm{~min}$. The supernatant was decanted and replaced with an equivalent volume of human serum. The solution was mixed and incubated at $4{ }^{\circ} \mathrm{C}$ overnight with gentle shaking. The serum solution was then filtered and stored at $-20{ }^{\circ} \mathrm{C}$ until required (Leake et al. 1987). 
Measurement of androgen receptors

The ability of cultured dermal papilla cells derived from non-balding $(n=5)$ and balding $(n=6)$ scalp hair follicles from 11 individuals to bind the radiolabelled androgen, mibolerone $\left(\left[17 \alpha-\right.\right.$ methyl- $\left.{ }^{3} \mathrm{H}\right]$ mibolerone; specific activity 3.05 TBq/mmol; NEN Laboratories, Stevenage, Herts, UK) was determined by saturation analysis in each of 11 primary cell lines, derived from different individuals, at passage 5. The precision of the assay was checked by parallel saturation analysis measurement of Shionogi cells $(n=5)$; it is not possible to derive the number of dermal papilla cells required to perform both androgen receptor and precision analysis from one sample. The androgen receptor assay methodology used is a modified version of Randall et al. (1992), cells were assayed when just sub-confluent. Mibolerone is not metabolised, does not bind to sex hormone binding globulin, and is more stable and receptor-selective than R1881, thereby making it a useful radioligand for use in whole cell binding assays (Murthy et al. 1985, Randall \& Mainwaring 1985).

Cells were seeded at $2 \times 10^{5}$ cells in each $100 \mathrm{~mm}$ tissue culture dish and grown to near confluency in normal growth medium. To reduce any endogenous androgens to a minimum, $24 \mathrm{~h}$ prior to the assay cells were washed three times in Dulbecco's phosphate buffered saline solution (PBS) and incubated in medium E199 containing $10 \% \quad(\mathrm{v} / \mathrm{v})$ dextran-coated, charcoal-stripped human female serum. This medium was then replaced with $5 \mathrm{ml}$ medium E199 containing 10\% (v/v) dextran-coated, charcoal-stripped female human serum containing a range of concentrations of $\left[{ }^{3} \mathrm{H}\right]$ mibolerone $(0 \cdot 05-10 \mathrm{nM}$; $9-10$ points) in the presence or absence of $200 \times$ excess unlabelled mibolerone to determine non-specific binding. Excess $(1000 \times)$ triamcinolone acetonide was also added to prevent any possible binding to progesterone receptors. After $2 \mathrm{~h}$ at $37^{\circ} \mathrm{C}$, aliquots of the medium were taken to measure the free, i.e. unbound radioactivity and the cells were washed four times in cold $\left(4^{\circ} \mathrm{C}\right) \mathrm{PBS}$ solution. The cells were removed using a cell scraper into glass centrifuge tubes containing PBS and collected by centrifugation (500 $\boldsymbol{g}$ for $10 \mathrm{~min}$ ). The supernatant was aspirated and the radioactive content of the cells extracted using chloroform:methanol $(1: 1 \mathrm{v} / \mathrm{v})$. The cellular lysate was collected by centrifugation $(500 \boldsymbol{g}$ for $10 \mathrm{~min}$ ) and the radioactivity in the supernatant was counted, after allowing the solvents to evaporate, using an LKB liquid scintillation spectrophotometer with a counting efficiency of around $50 \%$.

The number of cells present in the dishes at the time of the assay was determined by haemocytometric counting in triplicate, in each of two dishes reserved for this purpose. It was assumed that all dishes contained the same number of cells. Primary dermal fibroblasts derived from pubic skin were assayed similarly.
Investigations into the specificity of the receptors in non-balding and balding scalp dermal papilla cells

In order to confirm that the radiolabelled mibolerone was actually binding to specific androgen receptors, and to determine whether there were any differences between the receptors from the various sites, the ability of a range of androgens, antiandrogens and other classes of steroid hormones to inhibit the binding of $\left[{ }^{3} \mathrm{H}\right]$ mibolerone was investigated. Dermal papilla primary cell lines from balding $(n=4)$ and non-balding $(n=3)$ scalp hair follicles were prepared as described for the androgen receptor assay. Cells from each cell line were incubated separately with $1 \mathrm{nM}\left[{ }^{3} \mathrm{H}\right]$ mibolerone in quadruplicate or with $1 \mathrm{nM}$ $\left[{ }^{3} \mathrm{H}\right]$ mibolerone plus $100 \times$ excess $(100 \mathrm{nM})$ of a range of radioinert steroids in duplicate or triplicate for $2 \mathrm{~h}$ at $37^{\circ} \mathrm{C}$. The relative amounts of binding were then assessed as described previously.

\section{Determination of cellular protein content}

The cellular protein content of primary dermal papilla cell lines derived from balding and non-balding scalp hair follicles was determined using the standard Bradford protein assay (Bradford 1976).

\section{Statistical analysis}

Differences between the primary cell lines were analysed for significance using the non-parametric Mann-Whitney U-test and the Median test.

\section{Results}

\section{Androgen receptor assay}

Specific binding of $\left[{ }^{3} \mathrm{H}\right]$ mibolerone was saturated in each of the cell lines examined at around $1 \mathrm{nM}$ (Fig. 1a). Using this data Scatchard plots (Scatchard 1949) were constructed for each individual cell line, using a computer program (MS Excel 5.0), to provide an estimate of the affinity of the receptor for the ligand $\left(K_{\mathrm{d}}\right)$ and the number of binding sites available $\left(\mathrm{B}_{\max }\right)$ (Fig. $\left.1 b\right)$. The positive control cells, primary lines of genital skin fibroblasts $(n=2)$ and the Shionogi cells (assayed five times) contained high affinity, low capacity androgen receptors $\left(K_{\mathrm{d}}=0.15 \mathrm{nM}, \mathrm{B}_{\max }=0 \cdot 19 \mathrm{fmol} / 10^{4}\right.$ cells for genital skin fibroblasts, $K_{\mathrm{d}}=0 \cdot 23 \pm 0.04 \mathrm{nM}$ and $\mathrm{B}_{\max }=1 \cdot 05 \pm 0.04$ (mean \pm s.E.M.) for Shionogi cells). The coefficient of variation (C.V.) for the Shionogi cell assays was 3.7\%.

\section{Comparison of androgen binding by dermal papilla cell lines derived from non-balding and balding scalp hair follicles}

Saturable, high affinity binding was also detected in each of the dermal papilla cell lines derived from both balding $(n=6)$ and non-balding $(n=5)$ scalp hair follicles (Figs 2 and 

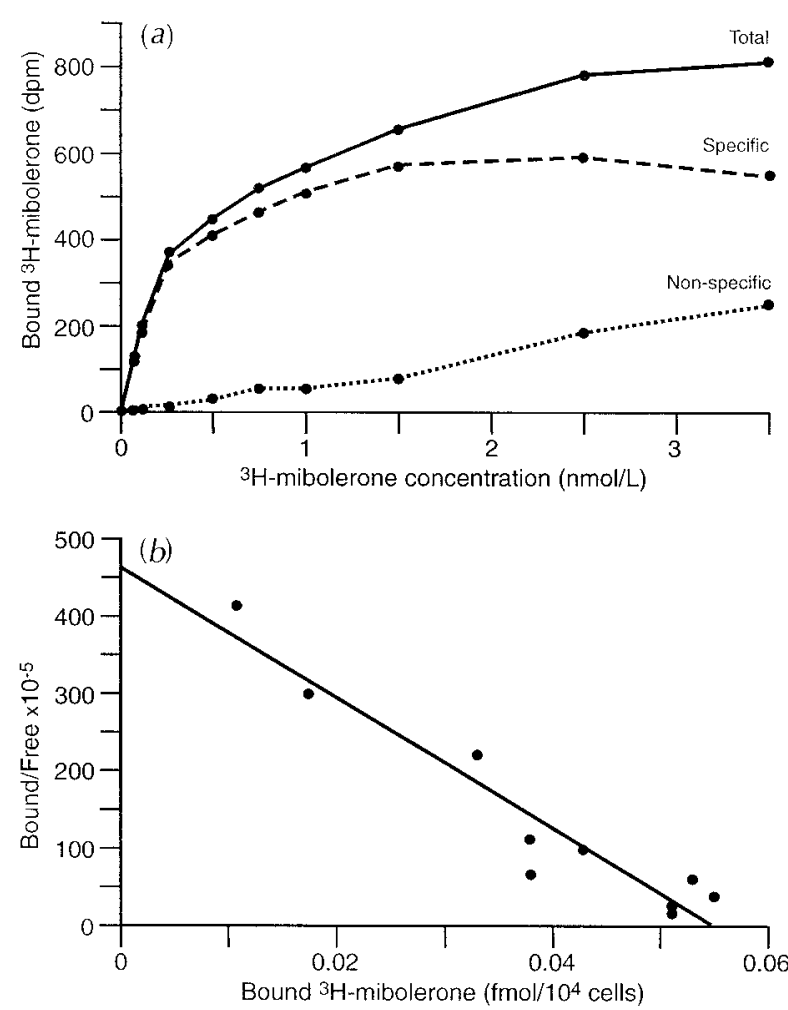

Figure 1 (a) A typical saturation analysis of $\left[{ }^{3} \mathrm{H}\right]$ mibolerone binding to the androgen receptor of a primary cell line of dermal papilla cells derived from balding scalp hair follicles. Cells were incubated for $2 \mathrm{~h}$ in medium E199 containing $\left[{ }^{3} \mathrm{H}\right]$ mibolerone $(0 \cdot 05-7.5 \mathrm{nM})$ in the presence or absence of $200 \times$ excess unlabelled mibolerone. A $1000 \times$ excess of triamcinolone acetonide was added to prevent any non-specific binding to progestin receptors. The specific binding was determined as the difference between the total binding $\left({ }^{3} \mathrm{H}\right]$ mibolerone alone) and non-specific binding $\left(\left[{ }^{3} \mathrm{H}\right]\right.$ mibolerone plus a $200 \times$ excess of unlabelled mibolerone). (b) Scatchard analysis of the specific binding data as described in Fig. $1 \mathrm{a}$. The binding affinity $\left(K_{\mathrm{d}}\right)$ was $0.22 \mathrm{nM}$ and the maximum binding capacity $\left(B_{\max }\right)$ was $0.078 \mathrm{fmol} / 10^{4}$ cells.

3). The binding affinities of the scalp dermal papilla cell lines were similar to those observed in the genital skin fibroblasts and there was no significant difference between the binding affinity of the balding $\left(K_{\mathrm{d}}=0 \cdot 22 \pm 0.03 \mathrm{nM}\right.$; mean \pm s.E.M. $)$ and non-balding $\left(K_{\mathrm{d}}=0 \cdot 26 \pm 0.06 \mathrm{nM}\right)$ scalp dermal papilla cell lines.

Dermal papilla cells derived from balding scalp hair follicles $\left(\mathrm{B}_{\max }=0 \cdot 06 \pm 0 \cdot 01 \mathrm{fmol} / 10^{4}\right.$ cells; mean \pm s.E.M., $n=6)$ contained significantly more androgen receptors than those derived from the non-balding ones $\left(\mathrm{B}_{\max }=0 \cdot 04 \pm\right.$ $0.001 \mathrm{fmol} / 10^{4}$ cells, $\left.n=5\right) \quad(P<0 \cdot 01 \quad$ Mann-Whitney U-test, $P<0 \cdot 05$ Median test) (Fig. 3). There was no significant difference in the cellular protein content between the dermal papilla cells derived from non-balding $\left(2.58 \pm 0.40 \mu \mathrm{g} / 10^{4}\right.$ cells; mean \pm s.E.M. $)$ and balding $\left(2 \cdot 57 \pm 0.47 \mu \mathrm{g} / 10^{4}\right.$ cells $)$ scalp hair follicles.

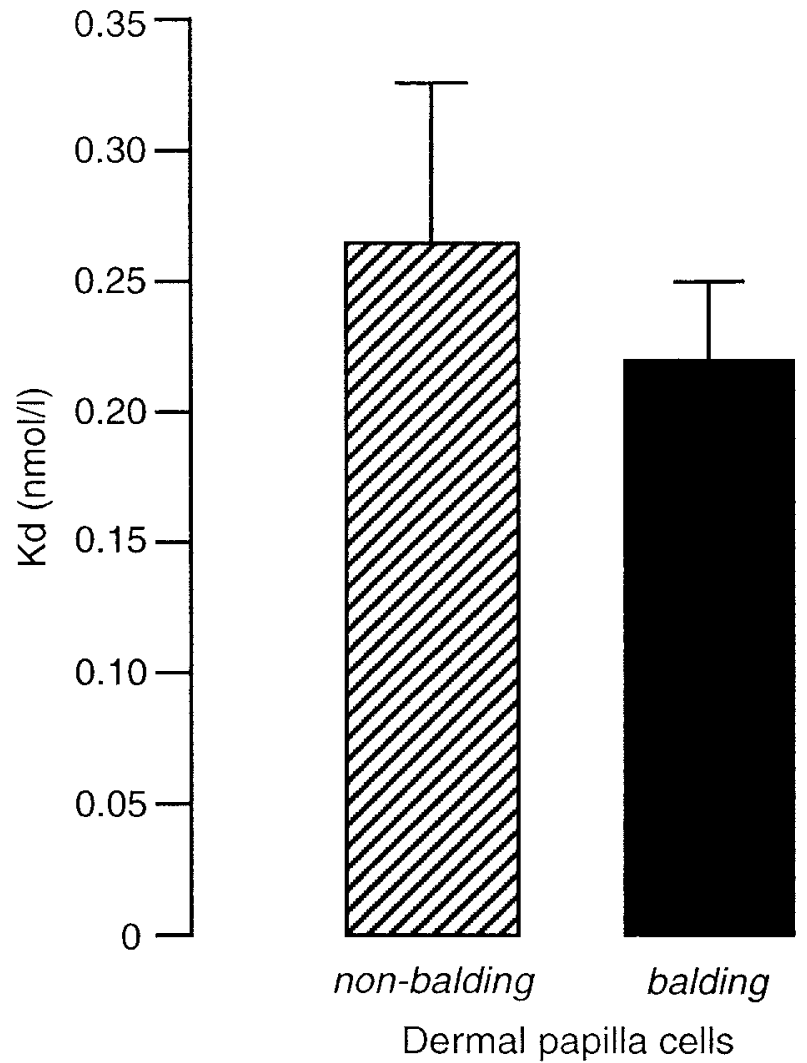

Figure 2 Similar binding affinity of the androgen receptors for $\left[{ }^{3} \mathrm{H}\right]$ mibolerone in primary cell lines of cultured dermal papilla cells derived from balding $(n=6)$ and non-balding $(n=5)$ scalp hair follicles. The binding affinity of each cell line was measured as described in Fig. 1.

Comparison of the steroid binding specificity of balding and non-balding dermal papilla cells

The androgens, testosterone, $5 \alpha$-dihydrotestosterone and mibolerone each significantly reduced the uptake of the radiolabelled mibolerone by about $85 \%$ in both cell types (Fig. 4). The antiandrogen, cyproterone acetate and $17 \beta-$ oestradiol were also effective competitors reducing the uptake of $\left[{ }^{3} \mathrm{H}\right]$ mibolerone by $50 \%$, but progesterone, triamcinolone acetonide and hydrocortisone had no effect. There was no difference in the competition patterns between the dermal papilla cells derived from balding $(n=4)$ and non-balding $(n=3)$ scalp hair follicles.

\section{Discussion}

This study has shown that dermal papilla cells derived from balding and non-balding scalp hair follicles contain specific, low capacity, high affinity androgen receptors. The assays were all carried out at passage 5 , so that the passage number should not affect the receptor levels. As the isolated androgen receptor has been shown to be 


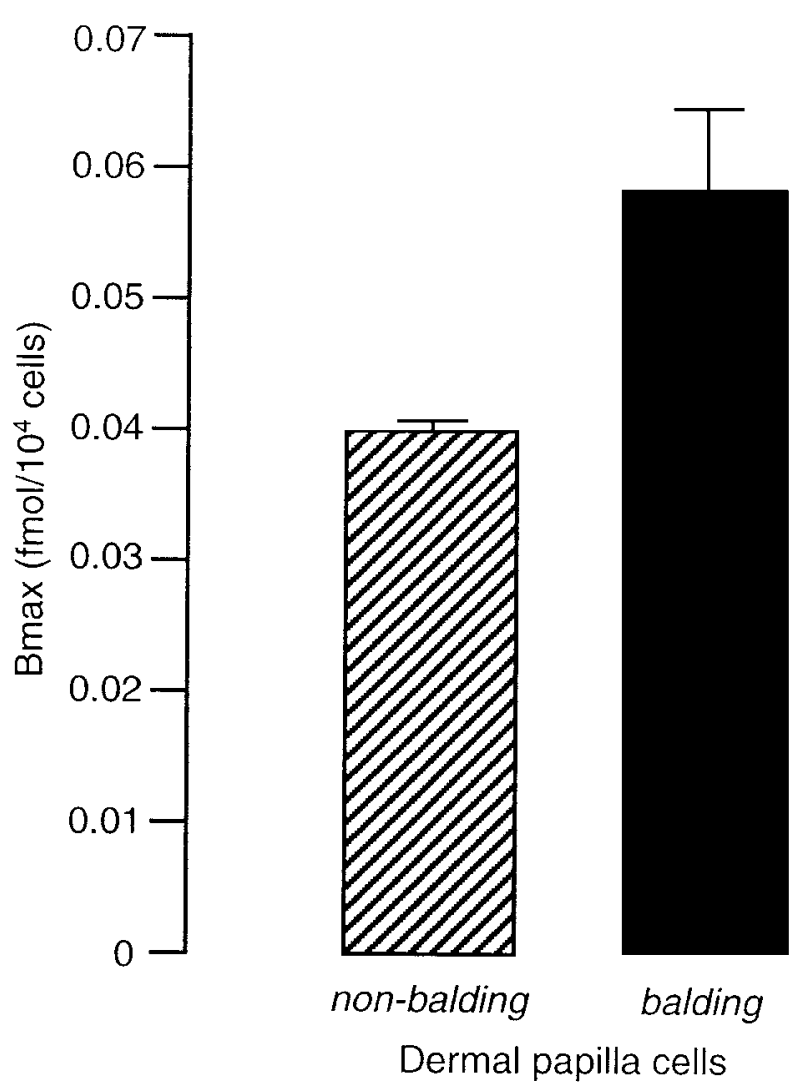

Figure 3 Greater levels of androgen receptors $\left(B_{\max }\right)$ were present in primary lines of cultured dermal papilla cells derived from balding scalp hair follicles $(n=6)$ compared with those from non-balding scalp hair follicles $(n=5)(P<0 \cdot 01)$. The concentration of receptors in each cell line was measured as described in Fig. 1.

extremely unstable (Randall \& Mainwaring 1985), a whole cell culture system was used to measure the androgen receptor content of these cells. Dermal papilla cells are known to exhibit aggregative behaviour in vitro (Messenger 1984), so that a single cell suspension is not appropriate. The approach used in this study involved cells attached to a solid support at the physiologically relevant temperature of $37^{\circ} \mathrm{C}$, thereby providing as normal conditions as possible. The method has been developed from that used previously to investigate androgen receptors in dermal papilla cells (Randall et al. 1992). In this study, cells were incubated in medium containing dextran-coated, charcoal-stripped human serum because we have previously found that balding scalp dermal papilla cells need human serum to grow and are unable to survive in serum-free medium conditions (Randall et al. 1996).

The methodology used in this study was validated by assaying two primary cell lines of pubic skin dermal fibroblasts and the continuous Shionogi cell line. Such cell lines have frequently been used to investigate androgendependent conditions such as the androgen insensitivity syndromes (Evans et al. 1984). Saturation of the androgen receptor by $\left[{ }^{3} \mathrm{H}\right]$ mibolerone in both cell lines occurred at $1 \mathrm{nM}$ and the $K_{\mathrm{d}}$ (binding affinity) and $\mathrm{B}_{\max }$ were similar to that described by previous studies (Syms et al. 1982, Jung-Testas \& Baulieu 1987, Gad et al. 1988). Since repetitive measurements of Shionogi cells androgen receptor content showed very little variation $(\mathrm{C} . \mathrm{V} .=3 \cdot 7 \%)$, this assay is sufficiently precise to measure levels of androgen receptors in cultured cells.

There was no significant difference in the $K_{\mathrm{d}}$ values obtained from balding and non-balding scalp dermal papilla cells, but dermal papilla cells derived from balding scalp hair follicles contained significantly greater levels of androgen receptors than those from non-balding scalp follicles. There was no correlation between donor age and androgen receptor content and the single female sample of non-balding skin contained the same levels as the male samples. These results are in agreement with those of Randall et al. (1992) who reported that androgendependent beard dermal papilla cells contained higher levels of androgen receptors than non-balding scalp cells. The non-specific binding was lower in this study than in an earlier one involving beard and scalp cells (Randall et al. 1992); this may reflect the presence of the stripped serum in this modified assay method. Similar studies on the seasonal red deer mane hair follicles have shown that the dermal papilla cells only contain androgen receptors if they are derived from androgen-dependent hair follicles when testosterone levels are raised in the autumn breeding season (Randall et al. 1993). All these results indicate that the androgen receptor content of cultured dermal papilla cells reflects the original androgen sensitivity of the body site from which they are derived.

The binding of $\left[{ }^{3} \mathrm{H}\right]$ mibolerone to the androgen receptor in both cell types was considerably inhibited by the androgens testosterone, mibolerone and $5 \alpha$-dihydrotestosterone, to a lesser extent by the antiandrogen cyproterone acetate and $17 \beta$-oestradiol, but only slightly, or not at all, by other types of steroids, thereby exhibiting the androgen receptor specificity of dermal papilla cells. The specificity demonstrated was also similar to that described in other cell types (Eil \& Edelson 1984, Randall et al. 1992). The absence of any difference in specificity between balding and non-balding dermal papilla cells suggests that balding is not due to abnormalities of the androgen receptor. This is consistent with the widely held view that there is only one androgen receptor in the body, supported by the wide ranging effects seen throughout the body in patients with a defect in the androgen receptor gene (Griffin \& Wilson 1989).

The presence of androgen receptors in rat follicular dermal papilla cells has also been demonstrated by autoradiographical techniques (Stumpf \& Sar 1976). Choudhry et al. (1992), using immunohistochemical methods, reported that dermal papilla cells in sections of human balding scalp follicles stained to a greater extent than those 


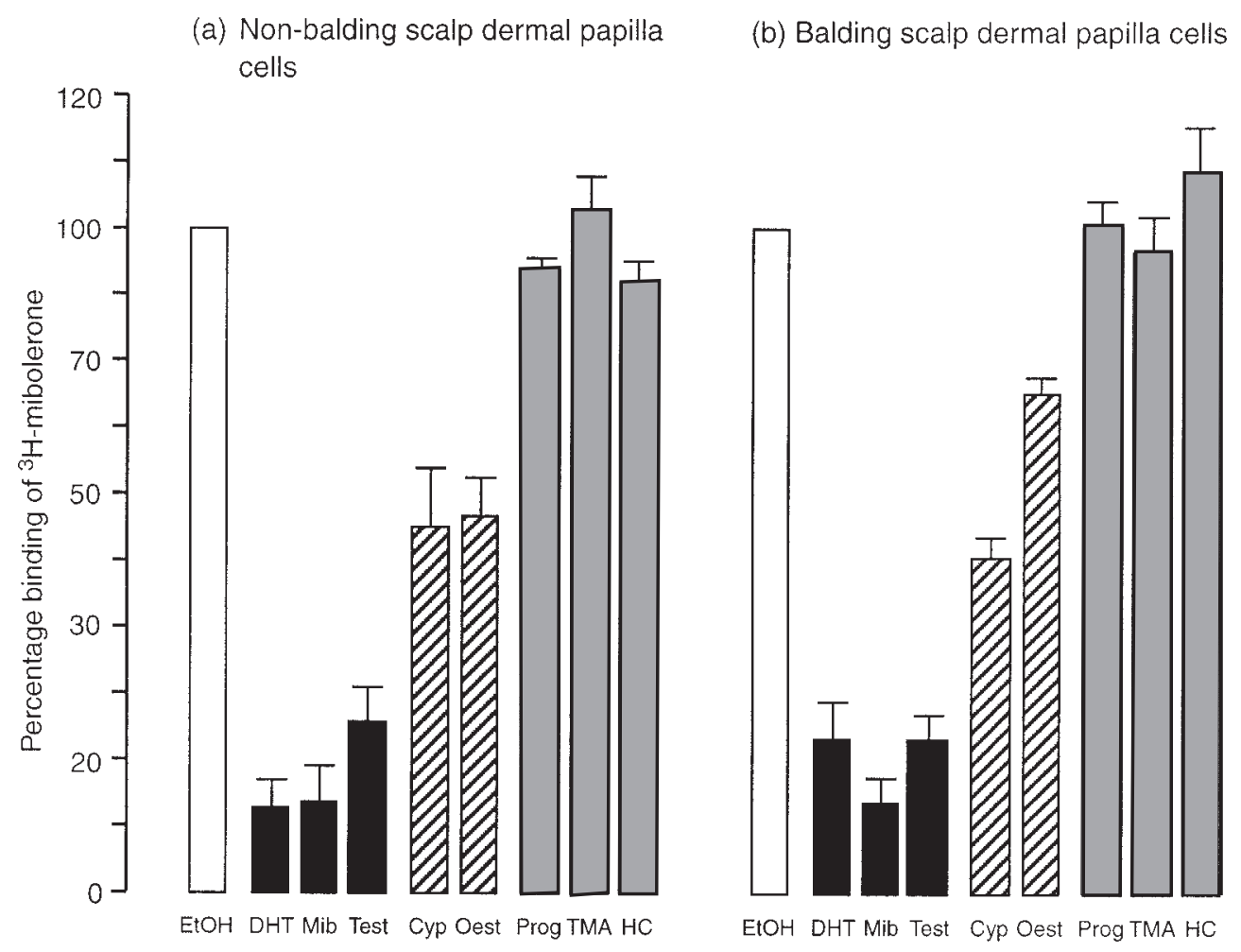

Figure 4 Binding specificity of androgen receptors in primary cell lines of cultured dermal papilla cells derived from (a) non-balding $(n=3)$, and (b) balding $(n=4)$ scalp hair follicles. Cells from each cell line were incubated separately for $2 \mathrm{~h}$ in medium E199 containing $1 \mathrm{nM}\left[{ }^{3} \mathrm{H}\right]$ mibolerone in the presence or absence of a $100 \times$ excess of androgens, antiandrogens and other classes of steroid hormones and the amount of binding was measured. $\mathrm{EtOH}$, ethanol vehicle alone; $\mathrm{DHT}$, $5 \alpha$-dihydrotestosterone; Mib, mibolerone; Test, testosterone; Cyp, cyproterone acetate; Oest, $17 \beta$-oestradiol; Prog, progesterone; TMA, triamcinolone acetonide; $\mathrm{HC}$, hydrocortisone.

from non-balding ones, thereby agreeing with the results of this study. In the stump tailed macaque, the main animal model of male pattern baldness (Uno et al. 1987), androgen receptor staining was seen in dermal papilla cells from both balding and non-balding hair follicles with no differences in the levels of expression, but balding occurs in both sexes in these animals. However, immunohistochemistry is still, primarily, a qualitative tool, and more precise quantitative techniques such as affinity binding with radiolabelled androgens as used in this study, are preferential for detecting the differences between bald and hairy skin.

The presence of higher levels of androgen receptors in cultured dermal papilla cells derived from balding scalp hair follicles is consistent with the hypothesis developed by Randall et al. (1991) that androgens act on the epithelial cells of the hair follicle via the mesenchyme-derived dermal papilla, causing the stimulation of some hair follicles (e.g. beard) whilst inhibiting others, as in male pattern baldness, altering the production of regulatory factors. Dermal papilla cells have been shown to secrete extracellular matrix components and mitogenic factors in culture (Messenger et al. 1991, Randall et al. 1991, Itami et al. 1995) and, very recently, it has been reported that androgens inhibit the production of mitogenic factors by cultured human balding scalp dermal papilla cells and those of the macaque (Hibberts \& Randall 1996, Obana \& Uno 1996). Further investigations using this model system should contribute to our understanding of the mechanisms of androgen action in androgenetic alopecia, and should lead, hopefully, to better treatments for this condition. The hair follicle has obvious parallels with other endocrine tissues such as the breast and prostate, where the mesenchymal cells, following steroid hormone induction, regulate the epithelial cells; in addition, the hair follicle, like the prostate, shows androgen-dependent age-related changes. Further studies of androgen action in cultured balding scalp dermal papilla cells may, therefore, also be relevant to our understanding of hormone-dependent cancer.

\section{Acknowledgements}

The preparation of the figures in this manuscript by $\mathrm{Mr}$ Chris Bowers is greatly appreciated. AEH was supported by the Tri-Mill Trust. 


\section{References}

Bradford M 1976 A rapid and sensitive method for the quantification of microgram quantities of protein utilising the principle of protein dye binding. Analytical Biochemistry 72 248-254.

Choudhry R, Hodgins MB, Van der Kwast TH, Brinkmann AO \& Boersma WJA 1992 Localisation of androgen receptors in human skin by immunohistochemistry: implications for the hormonal regulation of hair growth, sebaceous glands and sweat glands. Journal of Endocrinology 133 467-475.

Eil C \& Edelson SK 1984 The use of human skin fibroblasts to obtain potency estimates of drug binding to androgen receptors. Journal of Clinical Endocrinology and Metabolism 59 51-55.

Evans BAJ, Jones TR \& Hughes IA 1984 Studies of the androgen receptor in dispersed fibroblasts: investigation of patients with androgen insensitivity. Clinical Endocrinology 20 93-105.

Gad YZ, Berkovitz GD, Migeon CJ \& Brown TR 1988. Studies of up-regulation of androgen receptors in genital skin fibroblasts. Molecular and Cellular Endocrinology 57 205-213.

Griffin JE \& Wilson JD 1989 The resistance syndromes: $5 \alpha$-reductase deficiency, testicular feminisation and related disorders. In The Metabolic Basis of Inherited Disorders, pp 1919-1944. Eds CR Scriver, AL Baudet, WS Sly \& Valle. New York: McGraw-Hill.

Hamada K, Thornton MJ, Laing I, Messenger AG \& Randall VA 1996 The metabolism of testosterone by dermal papilla cells cultured from human pubic and axillary hair follicles concurs with hair growth in $5 \alpha$-reductase deficiency. Journal of Investigative Dermatology 106 1017-1024.

Hamilton JB 1942 Male hormone stimulation is a prerequisite and an incitant in common baldness. American Journal of Anatomy $\mathbf{7 1}$ 451-480.

Hamilton JB 1951 Patterned loss of hair in man. Annals of the New York Academy of Sciences $\mathbf{5 3}$ 708-728.

Hardy MH 1992 The secret life of the hair follicle. Trends in Genetics 8 55-61.

Hibberts NA \& Randall VA 1996 Testosterone inhibits the capacity of cultured balding scalp dermal papilla cells to produce keratinocyte mitogenic factors. In Hair Research in the Next Millennium, pp 303-306. Eds DJJ Van Neste \& VA Randall. Amsterdam, Netherlands: Elsevier Publishing.

Ibrahaim L \& Wright EA 1982. A quantitative study of hair growth using mouse and rat vibrissa follicles. Journal of Embryology and Experimental Morphology 72 209-224.

Imperato-McGuinley J, Miller M \& Wilson JD 1991 A cluster of male pseudohermaphrodites with $5 \alpha$-reductase deficiency in Papua New Guinea. Clinical Endocrinology 34 293-298.

Itami S, Kurata S, Sonada T \& Takayasu S 1991 Mechanism of androgen action in dermal papilla cells. Annals of the New York Academy of Sciences 642 385-395.

Itami S, Kurata S \& Takayasu S 1995 Androgen induction of follicular epithelial cell growth is mediated via insulin-like growth factor-I from dermal papilla cells. Biochemical and Biophysical Research Communications 212 988-994.

Jackson D, Church RE \& Ebling FJG 1972 Hair diameter in female baldness. British Journal of Dermatology 87 361-367.

Jung-Testas I \& Baulieu EE 1987 Testosterone-induced responsiveness to androgen in Shionogi mouse carcinoma cells. Experimental Cell Research 170 250-258.

Kligman AM 1959 The human hair cycle. Journal of Investigative Dermatology 33 301-316.

Leake RE, Freshney RI \& Miur I 1987 Steroid response in vivo and in vitro. In Steroid Hormones, pp 205-218. Eds B Green \& RE Leake. Oxford: IRL Press.

Lynfield YL 1960 Effects of pregnancy on the human hair cycle. Journal of Investigative Dermatology 35 323-327.

Messenger AG 1984 The culture of dermal papilla cells from human hair follicles. British Journal of Dermatology 110 685-689.
Messenger AG, Elliot KA, Temple A \& Randall VA 1991 Expression of basement membrane proteins and interstitial collagens in dermal papillae of human hair follicles. Journal of Investigative Dermatology 96 93-97.

Murthy LR, Rowley DR, Johnson MP, Young CYF, Scardino PT \& Tindall DJ 1985 Mibolerone has high affinity for both androgen and progesterone receptors in human prostate cytosol. Endocrinology 116 (Suppl 1) 167.

Obana IN \& Uno H 1996 Dermal papilla cells in macaque alopecia trigger a testosterone-dependent inhibition of follicular cell proliferation. In Hair Research in the Next Millennium, pp 307-310. Eds DJJ Van Neste \& VA Randall. Amsterdam, Netherlands: Elsevier Publishing.

Oliver RF 1970 The induction of hair formation in the adult hooded rat by vibrissa dermal papillas. Journal of Embryology and Experimental Morphology 23 219-236.

Randall VA 1994 Androgens and human hair growth. Clinical Endocrinology 40 439-457.

Randall VA \& Ebling FJG 1991 Seasonal changes in human hair growth. British Journal of Dermatology 124 146-151.

Randall VA \& Mainwaring VIP 1985 The assay of androgen receptor proteins. In Handbook on Receptor Research, pp 59-70. Ed F Auricchio. Rome: Field Educational Italia Acta Medica.

Randall VA, Thornton MJ, Hamada K, Redfern CPF, Nutbrown M, Ebling FJG \& Messenger AG 1991 Androgens and the hair follicle: cultured dermal papilla cells as a model system. Annals of the New York Academy of Sciences 642 355-375.

Randall VA, Thornton MJ \& Messenger AG 1992 Cultured dermal papilla cells from androgen-dependant human hair follicles (e.g. beard) contain more androgen receptors than those from non-balding areas of scalp. Journal of Endocrinology 133 141-147.

Randall VA, Thornton MJ, Messenger AG, Hibberts NA, Loudon ASI \& Brinklow BR 1993 Hormones and hair growth: variations in androgen receptor content of dermal papilla cells cultured from human and red deer (Cervus elaphus) hair follicles. Journal of Investigative Dermatology 101 114S-120S.

Randall VA, Hibberts NA \& Hamada K 1996 A comparison of the culture and growth of dermal papilla cells from hair follicles from non-balding and balding (androgenetic alopecia) scalp. British Journal of Dermatology 134 437-444.

Reynolds AJ \& Jahoda CAB 1991 Inductive properties of hair follicle cells. Annals of the New York Academy of Sciences 642 226-242.

Scatchard G 1949 The attraction of proteins for small molecules and ions. Annals of the New York Academy of Sciences 51 660-672.

Stenn KS, Paus R, Dutton T \& Sarba B 1993 Glucocorticoid effects on hair growth initiation: a reconsideration. Skin Pharmacology 6 125-134.

Stumpf WE \& Sar M 1976 Autographical localisation of estrogen, androgen, progestin and glucocorticosteroid in 'target tissues' and 'non-target tissues'. In Modern Pharmacology, Toxicology 8. Receptors and Mechanism of Action of Steroid Hormones Part 1, pp 41-54. Ed J Pasqualini. New York: Marcel Dekker.

Syms AJ, Harper ME, Battersby S \& Griffiths K 1982 Proliferation of human prostatic epithelial cell in culture: aspects of identification. Journal of Urology 127 561-567.

Thornton MJ, Laing I, Hamada K, Messenger AG \& Randall VA 1993 Differences in testosterone metabolism by beard and scalp hair follicle dermal papilla cells. Clinical Endocrinology 39 633-639.

Uno H, Cappas A \& Brigham P 1987 Action of topical minoxidil in the bald stump tailed macaque. Journal of the American Academy of Dermatology 16 657-668.

Van Scott EJ \& Ekel TM 1958 Geometric relationships between the matrix of the hair bulb and its dermal papilla in normal and alopecic scalp. Journal of Investigative Dermatology 31 281-287.

Received 6 June 1996

Revised manuscript received 9 May 1997 Accepted 7 August 1997 